\title{
From the Perspectives of Macroeconomic Factors: The Past and Future of Problematic Loans in Albania
}

\author{
Avenir Lleshanaku
}

\author{
Epoka University \\ Email: alleshanaku@epoka.edu.al; alleshanaku@bkt.com.al
}

\section{Doi:10.5901/ajis.2015.v4n1p35}

\begin{abstract}
There are a lot of risks that influence the ongoing performance in banking system and especially commercial banks, but, the credit risk is one of the highest one. The most important factor that indicates this performance is the level of nonperforming loans. It highly affects the bank stability each year. So, for this reason it is very important to manage them in the most effective way possible. For being able to manage these loans we must understand and know what are the main factors that indicate them are. There are different factors, such as macroeconomic and banking factors. The purpose of this paper is to analyze these factors in order to maintain the bank stability in the right way. This analyze is done for the Albanian banking system during the years 2000-2012. Factors included are the GDP rate, Real Interest Rate, Inflation Rate, Money Supply Growth Rate, and Unemployment Rate. The relation between these factors and NPLs show us the ongoing growth of the NPLs and how are affected.
\end{abstract}

Keywords: non-performing loans, macroeconomic factors, credit risk, Albanian banking system, GDP rate, unemployment rate, inflation rate, real interest rate, money supply

\section{Introduction}

Loan quality is one of the most important parts of deciding whether a bank is strongly financed or not and if it is managed properly. Past experiences shows that bad loans influence the economic crises and if they are highly build-up indicate as a good affect for improving the crises. As mentioned in the article of Andrew Campbell published in Pelgrave journals, "regular monitoring of loan quality, possibly with an early warning system capable of alerting regulatory authorities of potential bank stress, is thus essential to ensure a sound financial system and prevent systemic risk". Banks are highly influenced in their portfolio if the households and new businesses are strongly financed or if they are defined as businesses with high level of nonperforming loans.

"It is clear that Albania is affected by a high level of NPLs", said Michael Edwards responsible for operations in the financial sector of the World Bank. NPLs always have played on important role in financial transitional places. Nowadays the analyses for understanding the factors of these NPLs are mainly focused on the microeconomic and macroeconomic factors where banks operate.

While among the internal causes, one can be clearly distinguished from the rest. Looking back at the fast credit growth over the last years and the more recent increase in NPL, banks believe they could have been less aggressive with their growth targets. Given poor financial reporting and planning from clients (also identified as an external cause) banks are often put in a position of making decisions with low quality of data. This in turn results in poor evaluation of business potential, or of the financial situation at the time of approval and other factors that are identified as secondary internal causes by the banks. The recent trends in NPL and external events highlighted the important connection between low quality of reporting and planning in the Albanian businesses and the difficulties this creates for banks in making quality credit decisions.

Another approach to distinguish the reasons and causes of the rapid NPL's growth is to classify them into general, business and individuals reasons. Among the general reasons affecting the rapid growth of NPL's the economical crises, the currency depreciation, the ownership problem and the high cost of refinancing can be listed. Turning to the individual reasons the reduction of personal and familiar incomes, the remittance decline and the interruption of the employment relationship seem to be the most important ones, but there are also other individual reasons influencing like the unreliable income certificates and the slowdown of the wage growth. As a result of the Deloitte's survey the business loans constitute $79 \%$ of the NPL concentrations, so the business reasons leading to the increase in NPLs must be distinguished 
throughout. Among business reasons the most important one seems to be the slowdown in the construction sector as this sector constitutes the highest percentage of NPL according to industry. Other business reasons are the unstudied expansion of business, general lack of liquidity in the market, the liquidity problems transferred from one business to another, the export's contraction, the sales decline as a result of the purchasing power reduction and the loans overload.

The sharp rise in NPLs across the region has highlighted weaknesses in the partially-reformed legal frameworks in these transition countries, particularly laws and regulations dealing with debt collection, debt restructuring and bankruptcy/insolvency issues. Perhaps the most complicated legal issue associated with NPLs in the region is foreclosure. It is particularly difficult for banks in the region, including Albania, to take legal possession of movable collateral. Due to blocked court systems and other challenges in the legal process, the time required to accomplish a judicial foreclosure in most countries in the region is measured in years rather than months. In normal economic times, an efficient foreclosure process will therefore help to remove NPLs from banks' books, and will also help to increase the flow of credit to the economy.

During the survey of Deloitte among the banks, it was noted that about half of the banks were focused in reprogramming of loans and the other half in collecting the collateral as primary means of collecting assets from the distressed loans. None of the banks considered the sale of the NPL portfolio as an alternative they are focusing on at the moment. This stems primarily from the lack of a developed internal market for distressed assets. The key difficulties banks are facing in the attempt to reprogram the NPL loans are the difficulty to project cash flows due to significant fluctuations, the poor financial reporting by clients and the clients generally are not able to stick to reprogrammed terms. These three factors in combination make it very difficult to develop a reliable loan restructuring program on which the Bank can depend on for its credit risk management purposes. While the primary difficulties faced in collection of collateral is the prolonged and costly execution process, significant collateral accumulated with the bank takes time to convert to cash, value has decreased significantly due to market conditions or passage of time and difficulties to execute the collateral due to other claims. Such problems also impact the estimates that need to be made in regard to present value of collateral that can be collected, an amount that is crucial in evaluating credit risk reserves for these loans.

According to the publication of USAID about the NPL as the silent killers of the economic growth, Albania has been part of the "Over-Collateralization" challenge. Too often the type of collateral and its value are not correlated to the purpose or risk associated with a particular loan. Lenders take collateral as an abundance of caution. But the problem gets more difficult to handle if the collaterized assets become illiquid. In Albanian case, in order to provide more liquidity for the collaterized assets there is also the new legal framework on the third auction which will provide a less timeconsuming and expensive procedure for the execution of the collateral. In Albania, $60 \%$ of NPLs, or about 440 milion Euro, are to be written-off from banks' balance sheets. By writing-off of these NPLs the number will reduce to $17 \%$ of the total, improving the situation of the system and releasing banks in order to finance more individuals and businesses.

\section{Literature Review}

Lending is not an easy task for banks because it creates a big problem which is called NPLs. According to Alton and Hazen (2001) NPLs are those loans which are ninety days or more past due or no longer accruing interest. Hennie (2003) agrees arguing that NPLs are those loans which are not generating income. This is further supported by Caprio and Klingebiel (1996), cited in Fofack (2005), who define NPLs as those loans which for a relatively long period of time do not generate income that is, the principal and or interest on these loans have been left unpaid for at least ninety days. The term "bad loans" as described by Basu (1998) in Fofack (2005) is used interchangeably with non- performing and impaired loans. NPLs could be injurious to the financial performance of banking institutions. Greenidge and Grosvenor (2010), argue that the magnitude of NPLs is a key element in the initiation and progression of financial and banking crises and so does Reinhart and Rogoff (2010).

Over the years, there have been an increased number of significant bank problems in both, matured as well as emerging economies. Bank problems, mostly failures and financial distress have afflicted numerous banks, many of which have been closed down by regulatory authorities. Borio and Lowe (2002) observed that the cost of banking crises in terms of output loss has been high; typically double digit percentage of GDP. Many researches on the cause of bank failures find that asset quality is a statistically significant predictor of insolvency and that failing banking institutions always have high level of NPLs prior to failure. Bank insolvency has been a significant problem in many parts of the world in the last 30 years. There have been waves of bank failures in developed and developing countries and also in countries with transitional economies.

Jiménez et al. (2006) explained that the relationship between economic cycle and exposure of bank risk is 
dialectical. As economic conditions of the business worsen during a recession period in economy, the risk of intermediations tend to rise. In their study they found a negative relationship between GDP and nonperforming loans. The same result was found also by Salas et al. (2002), Gunsel (2008) and Thiagarajan et al. (2011). On the other hand, Fofack (2005), who studied the relationship between GPD and credit risk in Sub Saharan Africa, and Aver (2008) who studied this relation in the Slovenian banking system, have concluded that GPD and credit risk have no relationship with each other.

Another macroeconomic factor which affects the NPLs is also the Inflation Rate. The study of Gunsel (2008) implies that inflation is positively related with the credit risk in Euro Zone. Moreover, Vogiazas (2011) and Zribi (2011) found a negative relationship between inflation and credit risk on their cases of Romanian and Tunisian banking system. Also, in some other studies such as of Aver (2008) in Slovenian banking system, Bofondi (2011) in Italian banking system and Castro (2013) in GIPSI ${ }^{1}$ banking system was found no relation between inflation and credit risk.

Furthermore an important macroeconomic determinant of credit risk, thus of NPLs is also the Money Supply. An increase in MS will stimulate the investment and consumption and as result will increase the income. However, this increase will lower the Interest Rates thus customers will have cheaper funds. The relationship of MS and credit risk in Malaysia is studied by Ahmad (2003) and it is found to exist a significant and negative relationship between them. Similar results were found by Vogiazas et al. (2011) in Romanian banking system. The opposite results were found by Bofondi et al. (2011) in Italian banking system and no relationship was found by Fofack (2005) in Sub Saharan Africa banking system.

Interest Rate affects the debt burden of customers, as a result having an important effect in credit risk of banks. A rise in Interest Rate will raise the debt burden, thus will lead to an increase of the amount of NPLs. This statement is supported by many studies. According to Cebula (1999) real interest rate has a significant negative relationship with bank failure. Fofack (2005) found a positive relationship between interest rates and credit risk in Sub-Saharan Africa.

Moreover, an important of macroeconomic determinant of nonperforming loans is also unemployment in the economy. According to many studies such as Vogiazas (2011), and Bofondi (2011), unemployment is positively related with the amount of nonperforming loans. An increase in unemployment decreases the income of individuals, thus increase their debt burden and decrease their probabilities in paying their debts to their banks. (Louzis, 2012).

A financial intermediary is an institution that acts as an intermediary by matching supply and demand of funds (Beck, 2001). Heffernan (1996) defines banks as intermediaries between depositors and borrowers in an economy which are distinguished from other types of financial firms by offering deposit and loan products. Bossone (2001) agrees arguing that banks are special intermediaries because of their unique capacity to finance production by lending their own debt to agents willing to accept it and to use it as money. The traditional role of a bank is lending and loans make up the bulk of their assets (Njanike, 2009).

NPLs also have a lot of literature due to its importance for the survival of banks. Guy (2011) agrees arguing that NPLs have been widely used as a measure of asset quality among lending institutions and are often associated with failures and financial crises in both the developed and developing world. Despite ongoing efforts to control bank lending activities, NPLs are still a major concern for both international and local regulators (Boudriga et al, 2009).

The credit creation process works smoothly when funds are transferred from ultimate savers to borrower. There are many potential sources of risk during this process. According to Sinkey(1992) and Rose (1999) there are five major types of risk in banks: credit risk, liquidity risk, market risk, interest rate risk and profitability risk. Other studies provide other types of risk such as currency risk, investment risk, and economic decisions risk. Credit risk is most simply defined as the risk that a loan which has been granted by a bank, will not be either partially repaid on time or fully (Campbell, 2007), and where there is a risk of customer or counterparty default. However, credit risk is the biggest risk faced by banks and financial intermediaries. The indicators of credit risk include the level of NPLs, problem loans or provision for loan losses (Jiménez \&Saurina, 2006).

Keeton in 1999 analyzes the relation between the credit growth rate and the NPL ratio concluding that the fast growth rate of credit leads to higher loan losses and this relates to the supply shift that is an increased desire of the banks to give credit. The author stresses the fact that it will take 3 years that credit growth translate into NPL and as a result we have to analyze a long period to test statistically the fact that the fast credit growth leads to higher NPL. Haneef et al (2012) concluded that NPLs are increasing due to lack of risk management which threatens the profitability of banks. Akbari (2010) found that there are relationship between lack of controlling and monitoring before, during and after

${ }^{1}$ GIPSI - Greece, Ireland, Portugal, Spain and Italy 
granting facilities.

In order to be consistent with the study and the determinants examined in the Albanian case also the literature review is focused mainly in the macroeconomic determinants of credit risk leading to determinants of NPLS as well. Among many macroeconomic determinants encountered the ones that will be developed are: GDP growth, inflation rate, money supply, interest rate and unemployment rate.

According to the authors there is a strong relation between the NPL ratio and the economic cycle suggesting that in economic booms the NPL ratio tend to be low and in economic downturn the NPL ratio tend to be relatively high. Koch and McDonald (2003) suggest that in good economic condition both borrowers and lender are confident about investment project and their ability to repay their loans. This encourages banks to relax credit standards and accept more risk whereas Salas and Saurina (2002) and Bhattacharya and Roy (2008) suggest the opposite. During boom periods, the economic activities in general are increasing and the volume of cash held for either businesses or households is increasing. These conditions contribute of the increased ability of borrowers to repay loans, which leads to reducing of credit risk of banks. Khemraj and Pasha (2009) empirical results show that GDP growth is inversely related to NPLs, suggesting that an improvement in the real economy translates into lower NPLs. In case of Albania the study of Shingjergji 2013 proved a positive relation between GDP growth and NPL ratio.

In addition to this literature overview, this paper goes through a superficial analysis of banking sector and lending activity of Albania based in the Supervisions conducted by BoA and INSTAT; and also a synopsis of causes and determinants of NPLs as based in different studies and surveys made by Albanian researchers and companies

Arturo Bris, Professor of Finance at IMD Business School and Director of the World Competitiveness Centerm predicts that a global economic crisis is likely and that not enough action is being taken to avoid it. Based on statistics, he said that the world could expect a financial crisis as soon as April 2015, ending in March 2016. Bris said the cause of crisis will come from eight possible scenarios:

A stock market bubble - In the last year, stock markets have performed unrealistically well and at some point the situation will explode. In 2014 analysts were disappointed in the first quarter because earnings were not in line with market expectations. This means that if markets were to revert to a reasonable level with regards to earnings, there will be a stock market drop of between 30-35\%.

Banking in China - A severe crisis could be driven by growing Chinese shadow banking, a system which consists of loans mainly to government whose performance is not well monitored and not open to competition. If this system collapses, it will negatively affect the global economy.

Energy crisis - The United States, as the world's larger producer of gas, could cause an energy crisis. If the US begins exporting to the rest of the world, Russia might feel threatened, causing a geopolitical storm. The US would have control over energy prices and would exert influence over countries like the UL, India and Japan.

Another real estate bubble - There is risk of a property bubble forming in countries like Brazil, China, Canada or Germany. Prices are going up because availability of credit is huge and buyers are pushing prices up without realizing that they do not correspond to fundamental values.

Rating and bankruptcy: 'BBB as the new AA' - Companies currently have too much debt and the new norm is to have a BBB rating. In the US there are only three companies left with an AAA rating: ExxonMobil, Microsoft and Johnson \& Johnson. If the ratings are an indicator of bankruptcy, there will be bankruptcies across the board. If interest rates increased by $2 \%$, half of the corporate sector would be wiped out.

War and conflict - Almost everywhere, except in parts of Europe and the US, there is increasing geopolitical tension. Events like the current crisis the Crimea could trigger a market crash, even if there is no war.

Increasing poverty - Overall world poverty has increased and whenever the poor become poorer we can expect a social conflict. The crusade against income inequality could also further hinder innovation and growth by reducing the benefits of innovation, threatening the economy.

Cash and hyperinflation - The surplus of cash that central banks and corporations are holding could end up damaging the economy. The ECB is lending money to financial institutions that put it back into the ECB, which is vicious circle and today Google could afford to buy a majority stake in Ireland and Microsoft could buy more than $50 \%$ of Singapore, which is immoral.

"While many economies seem to be finally rebounding since the 2008 crisis, we shouldn't be complacent," Bris said. "Too often we do not learn from history and do not act when faced with a crisis we know is imminent." 


\section{Analysis of NPLs and Macroeconomic Factors in Albania}

The Albanian banking system continues to face serious difficulties in loans repayment. In fact it is to evidence that the major part of NPLs belong to the corporate sector showing the real difficulties of the Albanian business in the loan repayment. The last 5 years were characterized by a boom in lending activity fueled by a growing economy and significant increase in the level of banking intermediation. In recent years we saw a sharp increase in the level of NPLs in the Banking system triggered mainly by the effects of the economic crisis but also emphasized by other internal and external factors. The level of awareness of the banks in relation to the causes has increased significantly with the last years. It is clear that banks are taking or are willing to take important changes in the way the lending activity is conducted in order to adjust for material external events such as the crisis but also for other problems present in the environment such as: lack of reliable financial information, clients' poor business planning and execution, inefficient collateral collection processes etc.

Figure 1: Non-performing level from 1999 to 2012

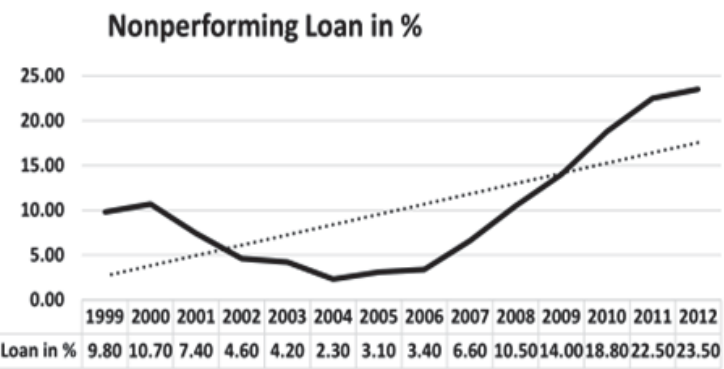

Source: World Bank

Figure 1 shows the trend of NPL rates in the last decade. Banking system in Albania has significantly increased over the last 10 years thus driving a boom in lending activities, yet compared to South and South-East Europe standards this credit boom is still low. Still the net margin in this sector is high. Moreover, during the recent years the profitability of the banks has decreased due to the increase in the NPL level. This increase mainly was caused by the latest global financial crisis. In 2012, NPL rate reached $23.5 \%$. Moreover, the linear trend line indicates that the NPL level has a tendency to increase.

More than half of the banks believe that the level of NPL in the Albanian Banking System is higher than what reported. This might indicate an expectation that NPL level is not going to decrease purely in the short term.

Figure 2: Level of agreement with \% of NPL as reported from the Bank of Albania

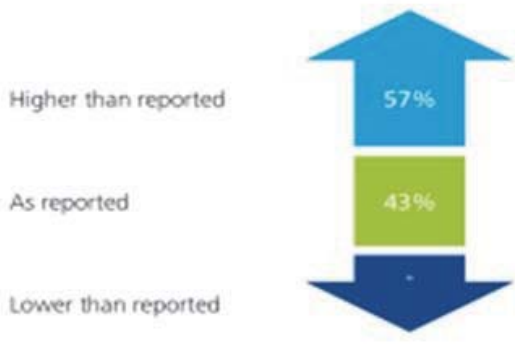

Source: Bank of Albania

The NPL seems to have affected more business loans. As such, about $79 \%$ of the banks reported their NPL portfolio to be concentrated in business and corporate loans rather than in consumer or individuals loans. It should be mentioned that business loans comprise also more than $70 \%$ of the total lending activity in Albania. 
Figure 3: Concentration of NPL

Business loans

consumer loans

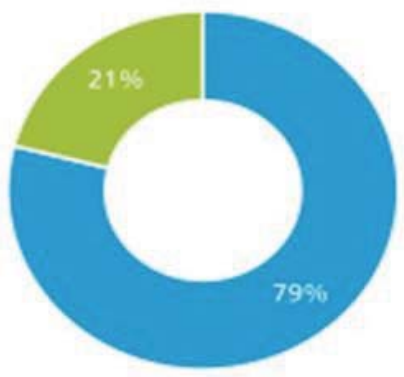

Source: Bank of Albania

Larger loans are also most exposed to performance problems. As a result, banks reported their NPL portfolio to be more present in loans disbursed at amounts of over Euro 200 thousand. According to a survey performed by Deloitte Albania, approximately $42 \%$ of NPL come from loans higher than 1 million Euros.

From the analyses through years, it was also noted that, from the group of business loans disbursed, the industry pinpointed as the most problematic was the Construction Industry. Indeed the Construction Industry, as reported by several reports, was affected considerably by the economic downturn of the last years and is currently experiencing a period with problems in sales and liquidity, thus affecting directly repayment capacity.

Figure 4: NPL distribution over industries

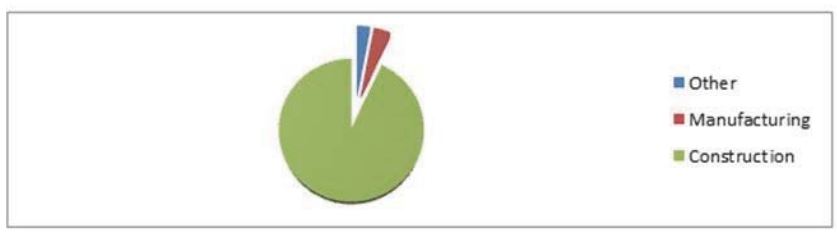

Source: Bank of Albania

The macroeconomic factors included in this paper are the real interest rate, GDP growth rate, inflation rate, money supply and unemployment rate.

Figure 5: Real Interest Rate (1996 - 2012)

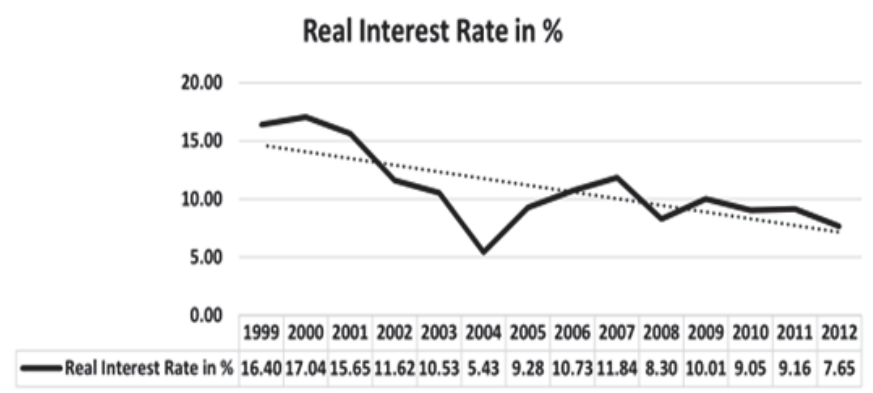

Source: World Bank database

Figure 5 shows the trend of real interest rate from 1999 to 2012. It had the biggest decline in 2004 when it fell from $10.53 \%$ in 2003 to 5.43\% in 2004 after that period it increased and in 2007 reached his highest peak in $11.84 \%$ after the 
90s and then decreased in $8.30 \%$ in 2008. In the last years it has been in level between 10-9\% but in 2012 it was 7.65\%, the lowest level after 2004. The linear tread line shows a steady tendency but yet declining. Even though steady, real interest rate is predicted to have a positive impact in NPL level and declining tendency is predicted to decrease the NPL level.

Figure 6: GDP growth rate (1999-2012)

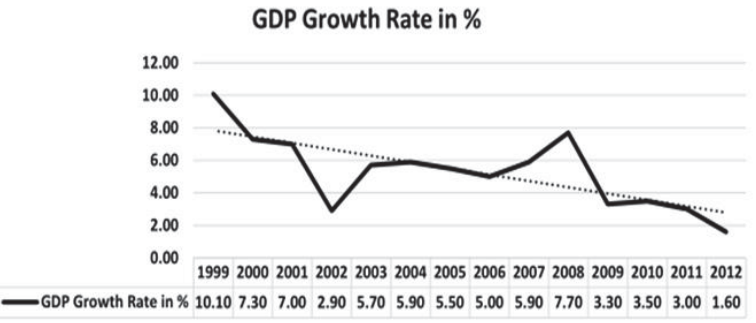

Source: World Bank database

Figure 6 shows the trend of GDP growth rate from 1999 to 2012. It had the highest increase from 2007 to 2008 by around $1.80 \%$ followed by the biggest decline in 2009 which from $7.70 \%$ it fell to $3.30 \%$, or it decreased by almost $4.4 \%$ almost 3 times more that it highest increase. In 2012 the growth rate is 1.60\%, the lowest level in the last decade. The linear tendency line shown that GDP has a high tendency to decline.

Figure 7: Inflation Rate (1999-2012)

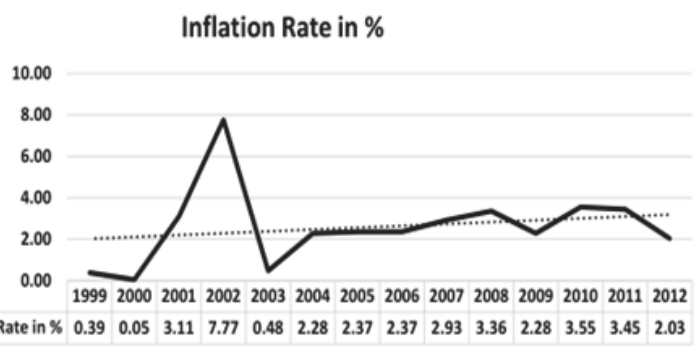

Source: World Bank database

Figure 7 shows the trend of inflation rate from 1999 to 2012. It had the highest increase in 2002 reaching the highest peak by $7.77 \%$ which immediately was followed by a sharp decline in the next year by approximately $7.29 \%$. However, in the last decade the highest increase was in 2004 when it increased by almost $1.80 \%$ while the lowest decrease it has in 2012 when it the level $2.03 \%$, or fell by almost 1.42\%. The highest peak of the last decade was 3.55\% in 2010 while the lowest was $0.48 \%$ in 2003 . The tendency line of inflation rate shows that inflation rate has a tendency to increase.

Figure 8: Money Supply growth rate (1999-2012)

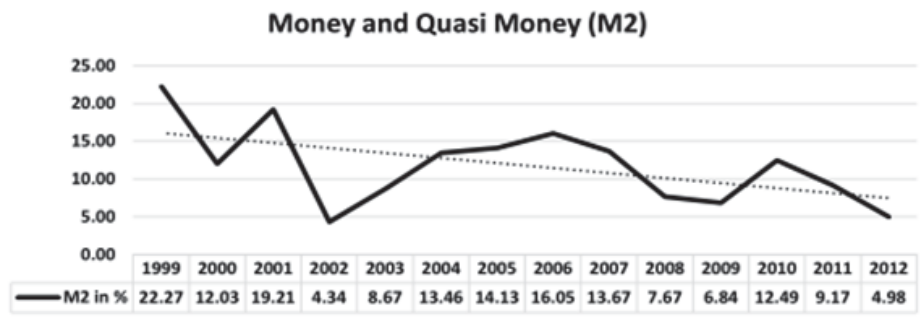

Source: World Bank database 
Figure 8 shows the trend of Money and Quasi Money Supply (M2) annual growth rate from 1999 to 2012. From 1999 to 2002, M2 had an ups and downs trend. During the last decade Money Supply growth rate increased and 2006 it reached the highest peak of 16.05\%. After 2006 till 2009 it declined to 6.84\% to rise again in 2010 to $12.49 \%$. In the following years it continued to fall steeply in 2011. In 2012 it has declined to 4.98\% reaching the lowest peak of the decade. The tendency line predicts a decline in Money supply. This tendency is predicted to worsen the situation of problematic loan because according to hypothesis a decrease in Money supply will increase level of non-performing loans.

Figure 9: Unemployment Rate (1999-2012)

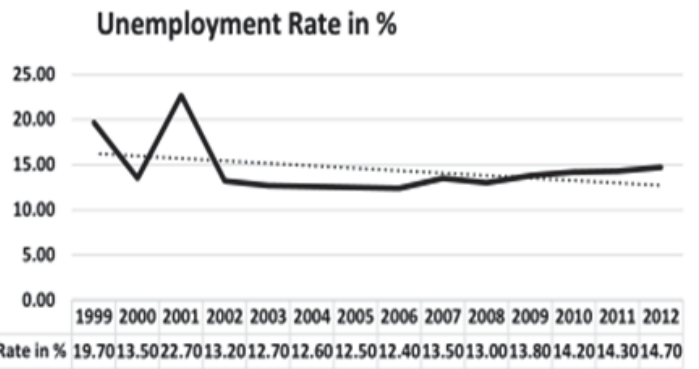

Source: World Bank database

Figure 9 shows the trend of unemployment rate from 1999 to 2012. The highest changes of unemployment rate are seen from 1999-2002 when it had a trend of consecutive sharp ups and downs. During the last decade it has lower by almost $4 \%$. The lowest level was $12.5 \%$ in 2008 . After this year mostly affected by the financial crises the unemployment level increase. In 2012 it reached the level of 13\%. The tendency line of unemployment rate shows that unemployment rate has a tendency to decline and according to the hypothesis this will improve the situation of problematic loans in Albania because it is predicted that a decrease in unemployment rate will lower the NPL level. However, the tendency line indicates that unemployment rate will decrease by a very small amount only.

\section{Theoretical Framework and Hypothesis Development}

In this paper are studied the following hypothesis which are based on the literatures mentioned above.

- H1: GDP has a negative impact in the amount of non-performing loans

- H2: An increase in Money Supply has a negative impact in the amount of non-performing loans

- H3: Real Interest Rate has a positive impact in the amount of non-performing loans.

- H4: Inflation Rate has a positive impact in the amount of non-performing loans.

- H5: Unemployment Rate has a positive impact in the amount of non-performing loans.

\subsection{Data and Methodology}

\subsubsection{Regression analyses}

The data used for this study are time series data from year 1993 to year 2012 and the source is the WB data base and the BoA database. The dependent variable is the amount of NPLs in Albania, while the independent variables are five macroeconomic variables as: GDP growth rate, Inflation Rate, Money Supply, Real Interest Rate, and Unemployment Rate. Multi-regression analysis is used in this analysis method.

Regression analysis is used when you want to predict a continuous dependent variable from a number of independent variables. If the dependent variable is dichotomous, then logistic regression should be used. (If the split between the two levels of the dependent variable is close to 50-50, then both logistic and linear regression will end up giving you similar results.) The independent variables used in regression can be either continuous or dichotomous. Independent variables with more than two levels can also be used in regression analyses, but they first must be converted into variables that have only two levels. This is called dummy coding and will be discussed later. Usually, regression analysis is used with naturally-occurring variables, as opposed to experimentally manipulated variables, 
although you can use regression with experimentally manipulated variables. One point to keep in mind with regression analysis is that causal relationships among the variables cannot be determined. While the terminology is such that we say that $X$ "predicts" $Y$, we cannot say that $X$ "causes" $Y$.

The model to be estimated is:

Eq. $1 \mathrm{NPL}=\beta 0+\beta 1 \mathrm{GDP}+\beta 2 \mathrm{M} 2+\beta 3 \mathrm{RIR}+\beta 4 \mathrm{INF}+\beta 5 \mathrm{UE}$

Where,

- NPL represents the ratio of bank nonperforming loans to total gross loans (\%).

- $\quad \beta 0$ is the intercept that represents the NPL ratio when all the independent variables are equal to 0 .

- GDP represents Gross Domestic Product growth rate (\%).

- $\beta 1$ is the expected slope of how much the NPL ratio will change for one percent of change of Gross Domestic Growth rate.

- $\mathrm{M} 2$ represents the M2 growth rate in \% (Money and Quasi Money supply)

- $\quad \beta 2$ is the expected slope of how much the NPL ratio will change for one percent of change of M2 rate.

- $\quad \mathrm{RIR}$ is Real Interest Rate (\%).

- $\quad \beta 3$ is the expected slope of how much the NPL ratio will change for one percent of change of Real Interest Rate.

- INF is the Inflation, consumer prices (annual \%).

- $\quad \beta 4$ is the expected slope of how much the NPL ratio will change for one percent of change of Inflation Rate.

- UE is the Unemployment Rate. (\%)

- $\quad \beta 5$ is the expected slope of how much the NPL ratio will change for one percent of change of unemployment rate.

After running the regression analysis with the Eviews program it resulted this equation: Eq. $2 \quad \mathrm{NPL}=-11.47$ 1.77 GDP - $0.59 \mathrm{M} 2-0.17 \mathrm{RIR}-1.63 \mathrm{INF}+1.46 \mathrm{UE}$ R2 $=0.51$

Figure 10: Regression of non-performing loans on independent variables

\begin{tabular}{|rrrrr|}
\hline \multicolumn{1}{|c}{ Variable } & Coefficient & Std. Error & t-Statistic & Prob. \\
\hline GDP & -1.770757 & 1.221295 & -1.449901 & 0.1851 \\
M2 & -0.593526 & 0.556984 & -1.065607 & 0.3177 \\
RIR & -0.174280 & 0.724351 & -0.240602 & 0.8159 \\
INF & -1.634544 & 1.099477 & -1.486657 & 0.1754 \\
UE & 1.462154 & 0.840883 & 1.738832 & 0.1203 \\
C & 11.47761 & 9.870424 & 1.162828 & 0.2784 \\
\hline R-squared & 0.513541 & Mean dependent var & & 10.10000 \\
Adjusted R-squared & 0.209504 & S.D. dependent var & 7.147673 \\
S.E. of regression & 6.354984 & Akaike info criterion & 6.833883 \\
Sum squared resid & 323.0866 & Schwarz criterion & 7.107765 \\
Log likelihood & -41.83718 & Hannan-Quinn criter. & 6.808530 \\
F-statistic & 1.689075 & Durbin-Watson stat & & 1.044700 \\
Prob(F-statistic) & 0.242735 & & \\
\hline
\end{tabular}

The figure 10 shows the beta coefficient of the macroeconomic variable included in the model. The results indicate that all the variables except unemployment rate have a negative impact on NPL ration. Thus, an increase in GDP growth rate, Money supply growth rate, Inflation Rate and Interest Rate will decrease the NPL ratio, while an increase in unemployment rate will increase the NPL ratio. The highest impact on NPL has the GDP growth rate will 1.77\% followed by inflation with $1.63 \%$ and unemployment rate with $1.46 \%$. While Real Interest Rate and Money supply impact NPL ration respectively only by $0.59 \%$ and $0.17 \%$. However, all the variables are statistically not significant, which shows that the relation between each individual variable and NPL ratio is not significant. The most significant variable in the model is unemployment rate with a p-value of 0.1209 . Moreover, R2 is equal to $0.51 \%$, thus the macroeconomic variables explains only the $51 \%$ of NPL ratio. As result other studies that included non-macroeconomic factors or more data should be conducted.

\subsubsection{Forecasting analyses}

In this paper is conduct also a forecasting analysis in order to forecast all the variables values use in regression analysis from 1999 to 2020. The historical data are from 1999 to 2012. The forecasting model had three components: the 
seasonal component, the irregular component and the trend component. Moreover, all the year have a respective code shown in column 't' such as 2003 has the code 1, 2004 has the code 2 as so on till 2020 which has the code 3.

Eq. $3 \mathrm{~V}=\mathrm{St} \times \mathrm{Ti} \times \mathrm{It}$

Central moving average calculates the three consecutive $V$ values. Then $V$ values are divided by the CMA in order to extract the seasonal and irregular component from the variable's data. The seasonal and irregular component (St $\times$ It) is the average of CMA and is call SI. V' is calculated by dividing V value by $(\mathrm{St} \times \mathrm{It})$ and it shows the values of $\mathrm{V}$ without seasonal and irregular components.

Eq. 4

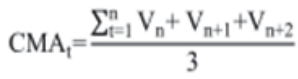

Eq. 5

$$
\mathrm{S} \& \mathrm{I} \text { comp }=\frac{\mathrm{V}_{\mathrm{t}}}{\mathrm{CMA}_{\mathrm{t}}}
$$

Eq. 6

$$
V^{\prime}=\frac{V}{S_{t} \times I_{t}}
$$

To calculate the trend component is conducted a multi regression analysis for the year 2003 to 2012 between ' $t$ ' values which represent the independent variable and 'Sl' values which represent the dependent variable. Trend component ( $\mathrm{Tt}$ ) is equal to the predicted ' $\mathrm{Sl}$ '.

$\begin{array}{ll}\text { Eq. } 7 & \mathrm{SI}=\beta_{0}+\beta_{1} \mathrm{t} \\ \text { Eq. } 8 & \mathrm{~T}_{\mathrm{t}}=\hat{\mathrm{Sl}}\end{array}$

Lastly the $V$ values are forecast for the year 2013 to 2022 which are equal to the product of all components together (See equation 1 and 2). The figures below show the results of the forecasting analysis.

Figure 11: Non-performing loans' level in past, present and also projected in future

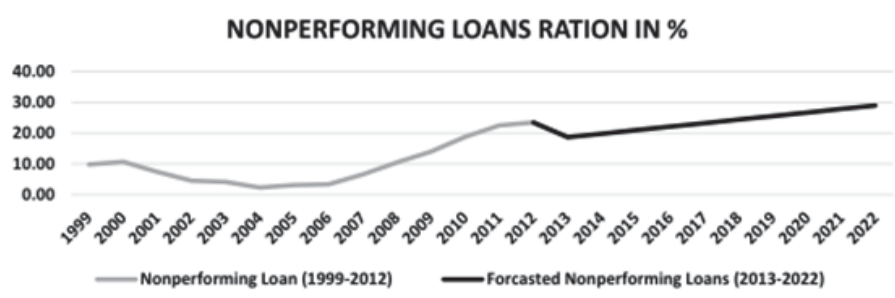

Author calculation

According to figure 11, the NPL level will continue to increase, meaning that the problematic loans in Albanian banking system will increase in number, thus the credit risk of the bank and the situation of financial intermediaries in Albania will worse.

Figure 12: GDP growth rate in past, present and also projected in future

\section{GDP Growth Rate in \%}

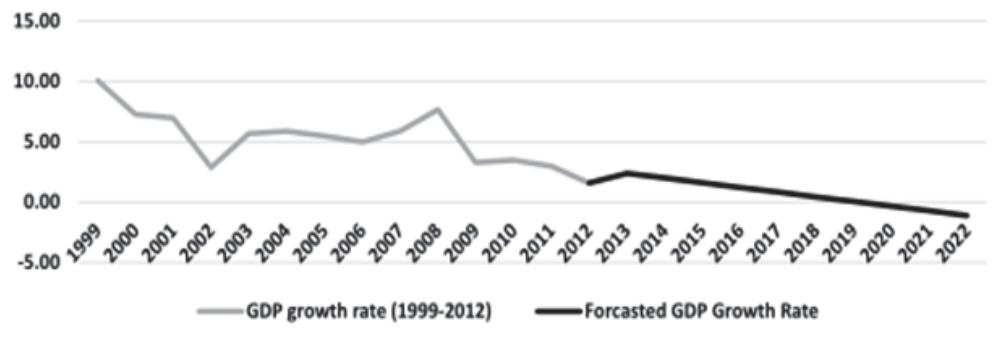

Author calculation

GDP growth rate is predicted to decrease to $2.3 \%$ in 2013 and $2 \%$ in 2014 while in 2020 it is predicted to reach the 
negative values of $-0.33 \%$ and worsening to $-1.01 \%$ in 2022 . According to the regression model results this significant decrease will cause an increase on NPL ratio by $1.77 \%$ for each percentage change. GDP growth rate has also the highest impact on NPL ratio according to the model, thus this substantial decrease will significantly increase the NPL ratio by around $4.78 \%$.

Figure 13: Money Supply growth rate in past, present and also projected in future

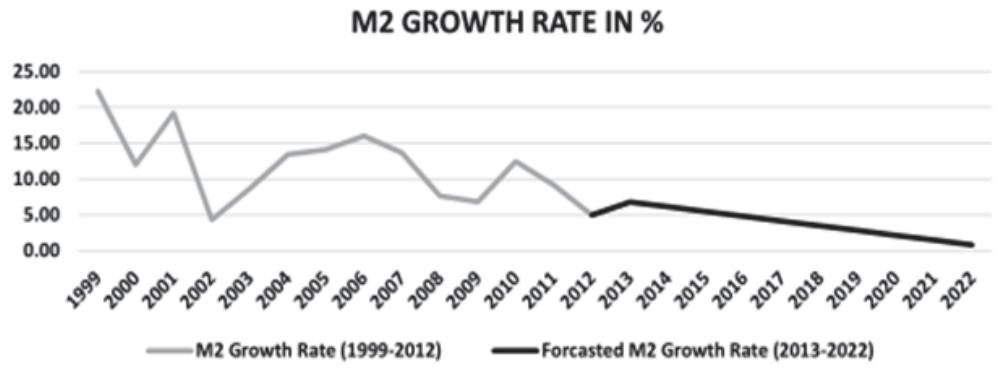

Author calculation

Also Money growth rate face a 1.82\% increase in 2013 from 4.98\% in 2012 followed by a long-time decrease (Figure 13). It is predicted that in 2022 it will reach to $0.83 \%$. According to the regression model results this decrease will cause an increase on NPL ratio by $1.59 \%$ for each percentage change. M2 growth rate has the second smallest impact in NPL ratio. However, the predicted decrease of more than $4 \%$ will cause of at least $2.36 \%$ increase of NPL ratio in the next 10 year if not offered by other factors or regulatory policies.

Figure 14: Real interest rate in past, present and also projected in future

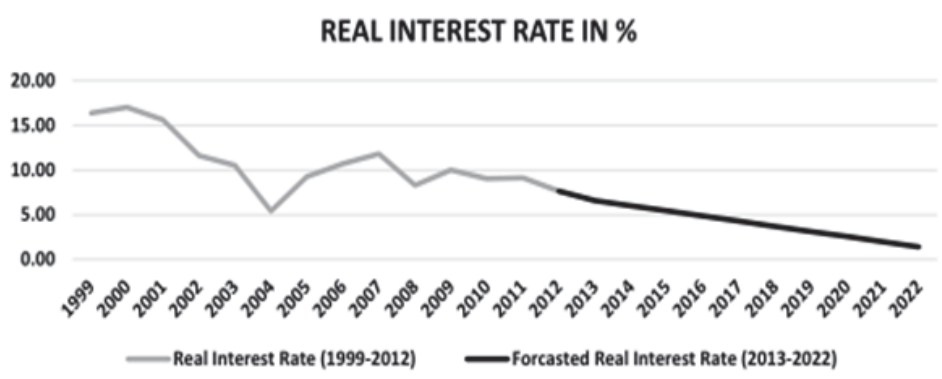

Author calculation

According to the forecasting analysis the real interest rate will decrease also. It will reach the level of 6.59 in $2013,3.71$ in 2018 and 1.41 in 2022 (Figure 14). According to the regression model results decrease will cause an increase on NPL ratio by $0.17 \%$ for each percentage change. This variable has the lowest impact in NPL ration according to the regression model and its decrease will increase the NPL ratio by less than $1 \%$. However, together will other variable its impact may be significant. 
Figure 15: Inflation rate in past, present and also projected in future

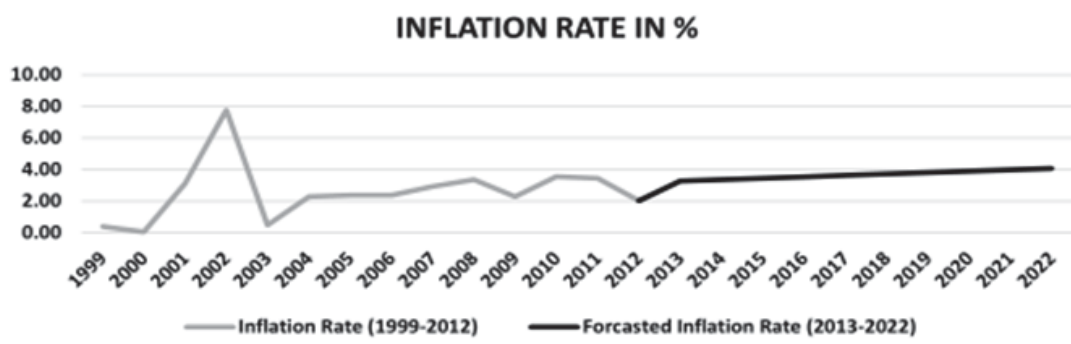

Author calculation

The inflation rate is predicted to increase in the next 10 year by only 2.5\%. In 2013, 2018, 2022 it will reach respect the level of $3.28 \%, 3.72 \%$ and $4.08 \%$ (Figure 15). According to the regression model results indicate that this increase will cause a decrease on NPL ratio by $1.63 \%$ for each percentage change. Although, that the inflation rate has the second most highest impact in NPL ratio for each percentage change, inflation rate increase not only is very low but also its impact is offset by the substantial decrease of GDP and also the decrease of money supply and real interest rate.

Also the unemployment is predicted to have a lowering effect on NPL ration in the next 10 years. The unemployment is predicted to just decrease by $5 \%$ in the next 10 years, thus decreasing the by around $7.45 \%$.

Figure 16: Unemployment rate in past, present and also projected in future

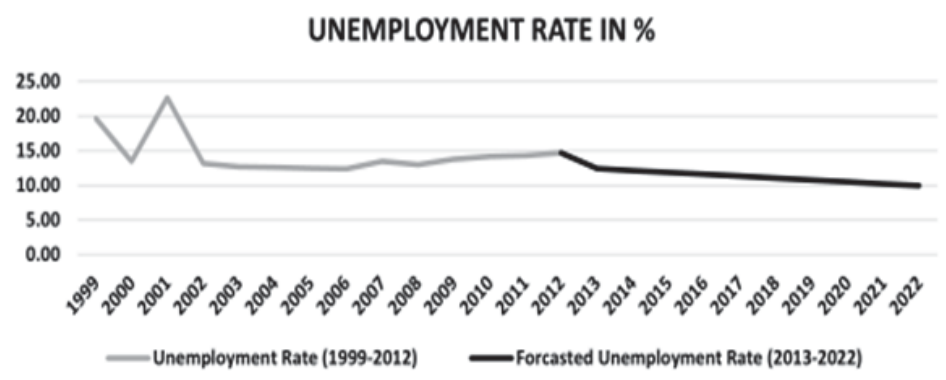

Author calculation

According to the regression and forecasting analysis the variable that will impact negatively in the NPL ratio, thus lowering it in the next 10 year, are unemployment and Inflation Rates. It is predicted that they will lower the ratio by around $11.5 \%$. Moreover, the variable that will have a positive effect on NPL ratio, thus increasing it, are the GDP growth rate, Inflation Rate and Interest Rate. Together they are predicted to increase the ratio by approximately $8 \%$. As concluded also in the regression analysis the fact that there is an overall $1.5 \%$ negative impact in NPL ratio while it is predicted to increase significantly indicates that there are other significant non macroeconomic variable that should be studied.

\section{Conclusions}

The recent financial crisis has revealed a need in analyzing the problems that caused the crisis in financing market in order to prevent future crisis. Nevertheless, before analyzing the triggers of the crisis, it is important to analyze the credit risk of banks and its factors that affect it. Before crisis burst, many banks suffer liquidity problems. Thus, the origin of the crisis is understood by analyzing credit risk and the situation of nonperforming loans. Nonperforming loans are very dangerous not only for the economy of one country but for the whole financial system in the world. In Albania the NPLS ratio is very concerning reaching levels of $23.1 \%$ of the total loans by setting the Albanian banking system in a higher credit risk. This credit risk has to be managed carefully by the supervisory authorities in order to avoid bankruptcies in the 
second level banks operating in Albania.

This paper analyzes the macroeconomic variables impact in the level of non-performing loans in Albanian banking system. This level in 2012 was $22.5 \%$ and if not carefully managed it may causes major problems in the second level banks. To analyze the impacted of the macroeconomic variable is conduct a multi regression and time series forecasting analysis. This study found that the NPL level is not significantly effected by any of the variable at significance level of $0.05 \%$, while at significance level of $0.1 \%$ only Money supply has a significant impact.

From the multi regression analysis it can be concluded that hypothesis one, two and five hold. These hypotheses predicted that GDP growth rate and Money Supply growth rate have a negative impact on nonperforming loans while Unemployment Rate has a positive impact in non-performing loans in Albanian banking system. On the other hand the hypothesis three and four do not hold. The hypothesis three predicted that Real Interest Rate and Inflation Rate have positive impact in non-performing loans in Albania, but the model predicted the opposite. Moreover, the time series analysis forecast that the nonperforming loans and inflation rate will increase while the GDP growth rate, Money Supply growth rate, Real Interest Rate and Unemployment Rate will decrease. Both the results of the analysis indicate an insignificant impact of variable in the NPL ratio. Thus, other non-macroeconomic determinants should be analyses in order to understand better the tendency of NPL ration and take actions accordingly.

The results can be beneficial to banks that operate in the Albanian banking system and to other financial institutions that operate in Albania. Due to the fact that this might be one of the first studies that cover this matter, thus it has implications for regulator, managers and policymaker. Also a beneficial of this study is that it covers the period of the latest financial crisis of 2008.

\section{References}

Albanian Bank. 2010. Semiannual Report.

Ahmad, N. H. (2003). Formation credit risk, regulatory price effect and the path linking credit to total risk. Universiti Utara Malaysia.

Aver, B. (2008). An empirical analysis of credit risk factors of the Slovenian banking system. Managing Global Transitions, 6(3), 317-334.

Biabani, Gilaninia, Mohabatkhah (2012). Assessment of Effective Factors on Non-Performing Loans (NPLs) Creation:Empirical Evidence from Iran (2006-2011). J. Basic. Appl. Sci. Res., 2(10)10589-10597.

BoA. (1998). Bank Accounting Manual. Tirana: Bank of Albania.

Bofondi, M., \& Ropele, T. (2011). MACROECONOMIC DETERMINANTS OF BAD LOANS: EVIDENCE FROM ITALIAN BANKS. Occasional Paper, 89.

Castro, V. (2013). Macroeconomic determinants of the credit risk in the banking system: The case of the GIPSI. Economic Modelling, 31, 672-683.

Cebula, R. J. (1999). New evidence on determinants of bank failures in the US. Applied Economics Letters, 6(1), 45-47.

Demirgüç-Kunt, A., \& Detragiache, E. (1998). The Determinants of Banking Crises in Developing and Developed Countries. Staff Papers-International Monetary Fund.

Festić, M., Kavkler, A., \& Repina, S. (2011). The macroeconomic sources of systemic risk in the banking sectors of five new EU member states. Journal of Banking \& Finance, 35(2).

Figlewski, S., Frydman, H., \& Liang, W. (2012). Modeling the effect of macroeconomic factors on corporate default and credit rating transitions. International Review of Economics \& Finance, 1, 87-105.

Fofack, H. (2005). Nonperforming loans in Sub-Saharan Africa: causal analysis and macroeconomic implications. Policy Research Working Paper Series(3769).

Gaganis, C., Pasiouras, F., Doumpos, M., \& Zopounidis, C. (2010). Modelling banking sector stability with multicriteria approaches. Optimization Letters, 4(4), 543-558.

Gunsel, N. (2008). Micro and Macro determinants of bank fragility in North Cyprus economy. African Journal of Business Management, 6(4), 13231329.

Jiménez, G., \& Saurina, J. (2006). Credit Cycles, Credit Risk, and Prudential Regulation. International Journal of Central Banking, 2(2), 65-98.

Laeven, L., \& Valencia, F. (2010). Resolution of Banking Crises: The Good, the Bad, and the Ugly. International Monetary Fund.

Llewellyn, D. (2002). An analysis of the causes of recent banking crises. The European journal of finance, 8(2), 152-175.

Louzis, D. P., Vouldis, A. T., \& Metaxas, V. L. (2012). Macroeconomic and bank-specific determinants of non-performing loans in Greece: A comparative study of mortgage, business and consumer loan portfolios. Journal of Banking \& Finance, 36(4), 1012-1027.

Santiago Fernández de Lis, Jorge Martínez Pagés and Jesús Saurina. (2000). Credit growth, problem loans and credit risk provisioning in Spain. Banco de España - Servicio de Estudios Documento de Trabajo n. ${ }^{\circ} 0018$.

Salas, V., \& Saurina, J. (2002). Credit Risk in Two Institutional Regimes: Spanish Commercial and Savings Banks. Journal of Financial Services Research, 22(3), 203-224.

Shijaku and Ceca. (2010). A model for credit risk in Albania using banks' panel data. Economic policies in SEE: design, performance and challenges. $53-72$.

Statistical data of the Albanian banking system: http://www.aab.al/al/statistics.php.

Statistical data from INSTAT institution: http://www.instat.gov.al/al/home.aspx.

Thiagarajan, S., Ayyappan, S., \& Ramachandran, A. (2011). Credit Risk Determinants of Public and Private Sector Banks in India. European Journal of Economics, Finance \& Administrative Sciences(34), 147-154.

Vogiazas, S. D., \& Nikolaidou, E. (2011). Credit risk determinants in the Bulgarian banking system and the Greek twin crises. MIBES, 177-189. 
Zameer, S., \& Siddiqi, M. W. (2010). The Impact of Exports, FDI and External Debt on Exchange Rate Volatility in Pakistan. Interdisciplinary Journal of Contemporary Research in Business, 2(7), 337-354.

Zribi, N., \& Boujelbène, Y. (2011). The factors influencing bank credit risk: The case of Tunisia. Journal of Accounting and Taxation, 3(4), 70-78.

Appendix: Forecasting Analyses

Table 1: Nonperforming loans' component calculation

\begin{tabular}{|c|c|c|c|c|c|c|c|}
\hline $\mathbf{t}$ & YEAR & NPL & CMA & NPL/CMA & St & NPL/St & Tt \\
\hline $\mathbf{1}$ & 1999 & 9.80 & & & 0.97 & 10.07 & 2.73 \\
\hline $\mathbf{2}$ & 2000 & 10.70 & 9.30 & 1.15 & 0.97 & 10.99 & 3.91 \\
\hline $\mathbf{3}$ & 2001 & 7.40 & 7.57 & 0.98 & 0.97 & 7.60 & 5.08 \\
\hline $\mathbf{4}$ & 2002 & 4.60 & 5.40 & 0.85 & 0.97 & 4.73 & 6.26 \\
\hline $\mathbf{5}$ & 2003 & 4.20 & 3.70 & 1.14 & 0.97 & 4.32 & 7.44 \\
\hline $\mathbf{6}$ & 2004 & 2.30 & 3.20 & 0.72 & 0.97 & 2.36 & 8.61 \\
\hline $\mathbf{7}$ & 2005 & 3.10 & 2.93 & 1.06 & 0.97 & 3.18 & 9.79 \\
\hline $\mathbf{8}$ & 2006 & 3.40 & 4.37 & 0.78 & 0.97 & 3.49 & 10.96 \\
\hline $\mathbf{9}$ & 2007 & 6.60 & 6.83 & 0.97 & 0.97 & 6.78 & 12.14 \\
\hline $\mathbf{1 0}$ & 2008 & 10.50 & 10.37 & 1.01 & 0.97 & 10.79 & 13.32 \\
\hline $\mathbf{1 1}$ & 2009 & 14.00 & 14.43 & 0.97 & 0.97 & 14.38 & 14.49 \\
\hline $\mathbf{1 2}$ & 2010 & 18.80 & 18.43 & 1.02 & 0.97 & 19.32 & 15.67 \\
\hline $\mathbf{1 3}$ & 2011 & 22.50 & 21.60 & 1.04 & 0.97 & 23.12 & 16.85 \\
\hline $\mathbf{1 4}$ & 2012 & 23.50 & & & 0.97 & 24.14 & 18.02 \\
\hline
\end{tabular}

Table 2: Regression Statistics for NPL level trend calculation

\begin{tabular}{|ccccc|}
\hline \multicolumn{2}{|c|}{ Regression Statistics } & & & \\
\hline Multiple R & 0.67 & & & \\
RSquare & 0.45 & & & \\
Adjusted R Square & 0.40 & & & \\
Standard Error & 5.67 & & & \\
Observations & 14 & & & \\
\hline & Coefficients & Standard Error & $P$-Value \\
\hline Intercept & 1.55 & 3.20 & 0.49 & 0.64 \\
T & 1.18 & 0.38 & 3.13 & 0.01 \\
\hline
\end{tabular}

Table 3: Gross Domestic Product's growth rate component calculation

\begin{tabular}{|c|c|c|c|c|c|c|c|}
\hline $\mathbf{t}$ & YEAR & GDP & CMA & GDP/CMA & St & GDP/St & Tt \\
\hline $\mathbf{1}$ & 1999 & 10.10 & & & 1.00 & 10.10 & 7.85 \\
\hline $\mathbf{2}$ & 2000 & 7.30 & 8.13 & 0.90 & 1.00 & 7.30 & 7.46 \\
\hline $\mathbf{3}$ & 2001 & 7.00 & 5.73 & 1.22 & 1.00 & 7.00 & 7.07 \\
\hline $\mathbf{4}$ & 2002 & 2.90 & 5.20 & 0.56 & 1.00 & 2.90 & 6.68 \\
\hline $\mathbf{5}$ & 2003 & 5.70 & 4.83 & 1.18 & 1.00 & 5.70 & 6.29 \\
\hline $\mathbf{6}$ & 2004 & 5.90 & 5.70 & 1.04 & 1.00 & 5.90 & 5.90 \\
\hline $\mathbf{7}$ & 2005 & 5.50 & 5.47 & 1.01 & 1.00 & 5.50 & 5.51 \\
\hline $\mathbf{8}$ & 2006 & 5.00 & 5.47 & 0.91 & 1.00 & 5.00 & 5.12 \\
\hline $\mathbf{9}$ & 2007 & 5.90 & 6.20 & 0.95 & 1.00 & 5.90 & 4.73 \\
\hline $\mathbf{1 0}$ & 2008 & 7.70 & 5.63 & 1.37 & 1.00 & 7.70 & 4.34 \\
\hline $\mathbf{1 1}$ & 2009 & 3.30 & 4.83 & 0.68 & 1.00 & 3.30 & 3.95 \\
\hline $\mathbf{1 2}$ & 2010 & 3.50 & 3.27 & 1.07 & 1.00 & 3.50 & 3.57 \\
\hline $\mathbf{1 3}$ & 2011 & 3.00 & 2.70 & 1.11 & 1.00 & 3.00 & 3.18 \\
\hline $\mathbf{1 4}$ & 2012 & 1.60 & & & 1.00 & 1.60 & 2.79 \\
\hline
\end{tabular}

Table 4: Regression Statistics for Gross Domestic Product Growth Rate trend calculation

\begin{tabular}{|ccccc|}
\hline \multicolumn{1}{|c|}{ Regression Statistics } & & & & \\
\hline Multiple R & 0.71 & & & \\
RSquare & 0.50 & & & \\
Adjusted R Square & 0.46 & & & \\
Standard Error & 1.69 & & & \\
Observations & 14 & & & \\
\hline & Coefficients & Standard Error & $t$ Stat & $P$-Value \\
\hline Intercept & 8.24 & 0.95 & 8.63 & 0.00 \\
T & -0.39 & 0.11 & -3.47 & 0.00 \\
\hline
\end{tabular}


Table 5: Money and Quasi Money Supply (M2) growth rate component calculation

\begin{tabular}{|c|c|c|c|c|c|c|c|}
\hline $\mathbf{t}$ & YEAR & M2 & CMA & M2/CMA & St & M2/St & Tt \\
\hline $\mathbf{1}$ & 1999 & 22.27 & & & 0.99 & 22.49 & 16.25 \\
\hline $\mathbf{2}$ & 2000 & 12.03 & 17.84 & 0.67 & 0.99 & 12.15 & 15.58 \\
\hline $\mathbf{3}$ & 2001 & 19.21 & 11.86 & 1.62 & 0.99 & 19.40 & 14.91 \\
\hline $\mathbf{4}$ & 2002 & 4.34 & 10.74 & 0.40 & 0.99 & 4.39 & 14.24 \\
\hline $\mathbf{5}$ & 2003 & 8.67 & 8.83 & 0.98 & 0.99 & 8.76 & 13.57 \\
\hline $\mathbf{6}$ & 2004 & 13.46 & 12.09 & 1.11 & 0.99 & 13.59 & 12.90 \\
\hline $\mathbf{7}$ & 2005 & 14.13 & 14.54 & 0.97 & 0.99 & 14.26 & 12.23 \\
\hline $\mathbf{8}$ & 2006 & 16.05 & 14.62 & 1.10 & 0.99 & 16.20 & 11.56 \\
\hline $\mathbf{9}$ & 2007 & 13.67 & 12.46 & 1.10 & 0.99 & 13.81 & 10.89 \\
\hline $\mathbf{1 0}$ & 2008 & 7.67 & 9.39 & 0.82 & 0.99 & 7.74 & 10.22 \\
\hline $\mathbf{1 1}$ & 2009 & 6.84 & 9.00 & 0.76 & 0.99 & 6.90 & 9.55 \\
\hline $\mathbf{1 2}$ & 2010 & 12.49 & 9.50 & 1.31 & 0.99 & 12.61 & 8.88 \\
\hline $\mathbf{1 3}$ & 2011 & 9.17 & 8.88 & 1.03 & 0.99 & 9.26 & 8.21 \\
\hline $\mathbf{1 4}$ & 2012 & 4.98 & & & 0.99 & 5.02 & 7.45 \\
\hline
\end{tabular}

Table 6: Regression Statistics for M2 growth rate trend calculatio

\begin{tabular}{|c|c|c|c|c|}
\hline \multicolumn{2}{|c|}{ Regression Statistics } & & & \\
\hline Multiple R & 0.53 & & & \\
\hline RSquare & 0.28 & & & \\
\hline Adjusted R Square & 0.22 & & & \\
\hline Standard Error & 4.66 & & & \\
\hline Observations & 14 & & & \\
\hline & Coefficients & Standard Error & t Stat & $P$-Value \\
\hline Intercept & 16.92 & 2.63 & 6.44 & 0.00 \\
\hline $\mathrm{T}$ & -0.67 & 0.31 & -2.17 & 0.05 \\
\hline
\end{tabular}

Table 7: Real Interest Rate's component calculation

\begin{tabular}{|c|c|c|c|c|c|c|c|}
\hline $\mathbf{t}$ & YEAR & RIR & CMA & RIR/CMA & St & RIR/St & Tt \\
\hline $\mathbf{1}$ & 1999 & 16.40 & & & 1.00 & 16.38 & 14.63 \\
\hline $\mathbf{2}$ & 2000 & 17.04 & 16.37 & 1.04 & 1.00 & 17.02 & 14.05 \\
\hline $\mathbf{3}$ & 2001 & 15.65 & 14.77 & 1.06 & 1.00 & 15.63 & 13.48 \\
\hline $\mathbf{4}$ & 2002 & 11.62 & 12.60 & 0.92 & 1.00 & 11.60 & 12.90 \\
\hline $\mathbf{5}$ & 2003 & 10.53 & 9.19 & 1.15 & 1.00 & 10.52 & 12.33 \\
\hline $\mathbf{6}$ & 2004 & 5.43 & 8.41 & 0.65 & 1.00 & 5.42 & 11.75 \\
\hline $\mathbf{7}$ & 2005 & 9.28 & 8.48 & 1.09 & 1.00 & 9.27 & 11.18 \\
\hline $\mathbf{8}$ & 2006 & 10.73 & 10.62 & 1.01 & 1.00 & 10.71 & 10.60 \\
\hline $\mathbf{9}$ & 2007 & 11.84 & 10.29 & 1.15 & 1.00 & 11.82 & 10.03 \\
\hline $\mathbf{1 0}$ & 2008 & 8.30 & 10.05 & 0.83 & 1.00 & 8.28 & 9.45 \\
\hline $\mathbf{1 1}$ & 2009 & 10.01 & 9.12 & 1.10 & 1.00 & 9.99 & 8.88 \\
\hline $\mathbf{1 2}$ & 2010 & 9.05 & 9.41 & 0.96 & 1.00 & 9.04 & 8.31 \\
\hline $\mathbf{1 3}$ & 2011 & 9.16 & 8.62 & 1.96 & 1.00 & 9.14 & 7.73 \\
\hline $\mathbf{1 4}$ & 2012 & 7.65 & & & 1.00 & 7.64 & 7.16 \\
\hline
\end{tabular}

Table 8: Regression Statistics for Real Interest Rate trend calculation

\begin{tabular}{|ccccc|}
\hline \multicolumn{1}{|c|}{ Regression Statistics } & & & & \\
\hline Multiple R & 0.71 & & & \\
RSquare & 0.50 & & & \\
Adjusted R Square & 0.46 & & & \\
Standard Error & 2.48 & & & \\
Observations & 14 & Standard Error & $t$ Stat & $P$-Value \\
\hline & Coefficients & 1.40 & 10.85 & 0.00 \\
\hline Intercept & 15.20 & 0.16 & -3.49 & 0.00 \\
\hline$T$ & -0.57 & & & \\
\hline
\end{tabular}

Table 9: Inflation Rate component calculation

\begin{tabular}{|c|c|c|c|c|c|c|c|}
\hline $\mathbf{t}$ & YEAR & INF & CMA & INF/CMA & St & INF/St & Tt \\
\hline $\mathbf{1}$ & 1999 & 0.39 & & & 0.97 & 0.40 & 2.09 \\
\hline $\mathbf{2}$ & 2000 & 0.05 & 1.18 & 0.04 & 0.97 & 0.05 & 2.19 \\
\hline $\mathbf{3}$ & 2001 & 3.11 & 3.64 & 0.85 & 0.97 & 3.22 & 2.28 \\
\hline $\mathbf{4}$ & 2002 & 7.77 & 3.79 & 2.05 & 0.97 & 8.05 & 2.37 \\
\hline $\mathbf{5}$ & 2003 & 0.48 & 3.51 & 0.14 & 0.97 & 0.50 & 2.46 \\
\hline
\end{tabular}




\begin{tabular}{|c|c|c|c|c|c|c|c|}
\hline $\mathbf{6}$ & 2004 & 2.28 & 1.71 & 1.33 & 0.97 & 2.36 & 2.56 \\
\hline $\mathbf{7}$ & 2005 & 2.37 & 2.34 & 1.01 & 0.97 & 2.45 & 2.65 \\
\hline $\mathbf{8}$ & 2006 & 2.37 & 2.56 & 0.93 & 0.97 & 2.46 & 2.74 \\
\hline $\mathbf{9}$ & 2007 & 2.93 & 2.89 & 1.02 & 0.97 & 3.04 & 2.83 \\
\hline 10 & 2008 & 3.36 & 2.86 & 1.18 & 0.97 & 3.48 & 2.93 \\
\hline 11 & 2009 & 2.28 & 3.06 & 0.74 & 0.97 & 2.36 & 3.02 \\
\hline 12 & 2010 & 3.55 & 3.09 & 1.15 & 0.97 & 3.68 & 3.11 \\
\hline 13 & 2011 & 3.45 & 3.01 & 1.15 & 0.97 & 3.57 & 3.20 \\
\hline 14 & 2012 & 2.03 & & & 0.97 & 2.10 & 3.30 \\
\hline
\end{tabular}

Table 10: Regression Statistics Inflation Rate trend calculation

\begin{tabular}{|ccccc|}
\hline \multicolumn{2}{|c|}{ Regression Statistics } & & & \\
\\
\hline Multiple R & 0.20 & & & \\
RSquare & 0.04 & & & \\
Adjusted R Square & -0.04 & & & \\
Standard Error & 1.98 & & & \\
Observations & 14.00 & & & \\
\hline & Coefficients & Standard Error & $t$ Stat & $P$-Value \\
\hline Intercept & 2.00 & 1.12 & 1.79 & 0.10 \\
T & 0.09 & 0.13 & 0.70 & 0.49 \\
\hline
\end{tabular}

Table 11: Unemployment Rate components calculation and forecasting

\begin{tabular}{|c|c|c|c|c|c|c|c|}
\hline $\mathbf{t}$ & YEAR & UE & CMA & UE/CMA & St & UE/St & Tt \\
\hline $\mathbf{1}$ & 1999 & 19.70 & & & 0.99 & 19.87 & 16.41 \\
\hline $\mathbf{2}$ & 2000 & 13.50 & 18.63 & 0.72 & 0.99 & 13.62 & 16.13 \\
\hline $\mathbf{3}$ & 2001 & 22.70 & 16.47 & 1.38 & 0.99 & 22.90 & 15.85 \\
\hline $\mathbf{4}$ & 2002 & 13.20 & 16.20 & 0.81 & 0.99 & 13.32 & 15.58 \\
\hline $\mathbf{5}$ & 2003 & 12.70 & 12.83 & 0.99 & 0.99 & 12.81 & 15.30 \\
\hline $\mathbf{6}$ & 2004 & 12.60 & 12.60 & 1.00 & 0.99 & 12.71 & 15.03 \\
\hline $\mathbf{7}$ & 2005 & 12.50 & 12.50 & 1.00 & 0.99 & 12.61 & 14.75 \\
\hline $\mathbf{8}$ & 2006 & 12.40 & 12.80 & 0.97 & 0.99 & 12.51 & 14.48 \\
\hline $\mathbf{9}$ & 2007 & 13.50 & 12.97 & 1.04 & 0.99 & 13.62 & 14.20 \\
\hline $\mathbf{1 0}$ & 2008 & 13.00 & 13.43 & 0.97 & 0.99 & 13.11 & 13.92 \\
\hline $\mathbf{1 1}$ & 2009 & 13.80 & 13.67 & 1.01 & 0.99 & 13.92 & 13.65 \\
\hline $\mathbf{1 2}$ & 2010 & 14.20 & 14.10 & 1.01 & 0.99 & 14.33 & 13.37 \\
\hline $\mathbf{1 3}$ & 2011 & 14.30 & 14.40 & 0.99 & 0.99 & 14.43 & 13.10 \\
\hline $\mathbf{1 4}$ & 2012 & 14.70 & & & 0.99 & 14.83 & 12.82 \\
\hline
\end{tabular}

Table 12: Regression Statistics for Unemployment Rate Trend Calculation

\begin{tabular}{|cccc|}
\hline & Regression Statistics & & \\
& & & \\
Multiple R & 0.38 & & \\
RSquare & 0.15 & & \\
Adjusted R Square & 0.08 & & \\
Standard Error & 2.90 & & \\
Observations & 14.00 & Standard Error & $t$ Stat \\
\hline & Coefficients & 1.64 & 10.19 \\
\hline Intercept & 16.68 & 0.19 & 1.43 \\
\hline
\end{tabular}

Table 13: Forecasted Variables

\begin{tabular}{|c|c|c|c|c|c|c|}
\hline YEAR & NPL & GDP & M2 & RIR & INF & UE \\
\hline $\mathbf{2 0 1 3}$ & 18.69 & 2.40 & 6.81 & 6.59 & 3.27 & 12.44 \\
\hline $\mathbf{2 0 1 4}$ & 19.83 & 2.01 & 6.14 & 6.02 & 3.36 & 12.16 \\
\hline $\mathbf{2 0 1 5}$ & 20.98 & 1.62 & 5.48 & 5.44 & 3.45 & 11.89 \\
\hline $\mathbf{2 0 1 6}$ & 22.12 & 1.23 & 4.82 & 4.87 & 3.54 & 11.61 \\
\hline $\mathbf{2 0 1 7}$ & 23.27 & 0.84 & 4.15 & 4.29 & 3.63 & 11.34 \\
\hline $\mathbf{2 0 1 8}$ & 24.41 & 0.45 & 3.49 & 3.72 & 3.72 & 11.07 \\
\hline $\mathbf{2 0 1 9}$ & 25.56 & 0.06 & 2.83 & 3.14 & 3.81 & 10.79 \\
\hline $\mathbf{2 0 2 0}$ & 26.70 & -0.33 & 2.16 & 2.56 & 3.90 & 10.52 \\
\hline $\mathbf{2 0 2 1}$ & 27.85 & -0.72 & 1.50 & 1.99 & 3.99 & 10.25 \\
\hline $\mathbf{2 0 2 2}$ & 28.99 & -1.10 & 0.84 & 1.41 & 4.08 & 9.97 \\
\hline
\end{tabular}

